\title{
EFFECTS OF STERILIZATION AND TEMPERATURE ON THE DECREASE KINETIC OF PHOSPHORUS BIOAVAILABILITY IN TWO DIFFERENT SOIL TYPES
}

\author{
Ali Akbar Safari Sinegani ${ }^{1 *}$ and Serveh Sedri \\ Faculty of Agriculture, Bu-Ali Sina University, Hamedan, Iran. \\ *Corresponding author: aa-safari@basu.ac.ir
}

\begin{abstract}
The aim of this work was to study the effects temperature and microbial activity on the decrease kinetic of availabile P in two different soil types. Surface soils were sampled from Guilan and Hamadan provinces in north and northwest of Iran with temperate and semiarid climates. The availability of $\mathrm{P}$ in soil samples was studied in two (sterile and unsterile) conditions after addition of $400 \mathrm{mg} \mathrm{P} \mathrm{kg}{ }^{-1}$ soil as $\mathrm{KH}_{2} \mathrm{PO}_{4}$. Treated soil samples incubated in field capacity up to $2880 \mathrm{~h}$ at 15 and $28{ }^{0} \mathrm{C}$ in 3 replicates. Separate batches were taken after $0.16,0.5,1,3,12,24,48,168,336,720,1440,2160$, and $2880 \mathrm{~h}$ for extraction with $0.5 \mathrm{M} \mathrm{NaHCO}_{3}$. Temperate soils had higher clay content, cation exchange capacity (CEC), organic carbon (OC), total nitrogen, biological activity, amorphous and crystalline $\mathrm{Fe}$ and $\mathrm{Al}$, but semiarid soils had higher sand content, $\mathrm{pH}$, equivalent carbonate calcium (EEC), available $\mathrm{P}$ and $\mathrm{K}$. Soil properties and sterilization had significant effect on $\mathrm{P}$ bioavailability after soil treatment with $\mathrm{P}$ fertilizers. The temperate soils with high affinity surface sites for $\mathrm{P}$ sorption compared to semiarid soils, had a lower available $\mathrm{P}$ in each time of extraction. Soil sterilization reduced the rate of $\mathrm{P}$ sorption/precipitation processes in initial step. The $\mathrm{NaHCO}_{3}$ extractable $\mathrm{P}$ in sterilized soils decreased continuously in first 30 days of soil incubation. After that soil available P did not decrease in sterilized soils significantly. However in unsterile soils after the initial decrease of available $\mathrm{P}$, the bioavailability of $\mathrm{P}$ due to soil microbial activity increased. In sterile soils the first order equation, second order equation, Elovich kinetic equation, and power function equation could describe the adsorptive/precipitate process. The second order model and Elovich kinetic equation were selected to express the sorption/precipitation behavior in sterile soils because of the high $\mathrm{R}^{2}$ values. The models selected suggest that the sorption mechanism in sterile soils is greatly chemisorption process. However in unsterile soils incubated at $15^{\circ} \mathrm{C}$ the suitability of the tested equations was considerably low. This study showed that soil biological activity had considerable effects on available $\mathrm{P}$ and its decrease kinetic after $\mathrm{P}$ addition to soil.
\end{abstract}

Keywords: Phosphorus; bioavailability; temperature; sterile soils; kinetic models.

\section{INTRODUCTION}

Compared with the other major nutrients, phosphorus is by far the least mobile and available to plants in most soil conditions.
Although phosphorus is abundant in soils in both organic and inorganic forms, it is frequently a major or even the prime 
limiting factor for plant growth (Khan et al., 2007).

To circumvent phosphorus deficiency, phosphate- solubilizing microorganisms (PSM) could play an important role in supplying phosphate to plants in a more sustainable way (Khan et al., 2007). As it was reported earlier, number of soil bacteria possesses mineral phosphate solubilizing activity (Yahya and AlAzawi, 1989). The PSM largely include bacteria and fungi, especially some of the species of Bacillus, Pseudomonas, Penicillium and Aspergillus (Tilak et al., 2005). The PSM can solubilize and mineralize $\mathrm{P}$ from inorganic and organic pools of total soil $\mathrm{P}$ and may be used as inoculants, in order to increase plant Pavailability (Whitelaw et al., 1999). In addition, the PSM also have the capacity to increase the growth and yield of crop plants (Ozgonen et al., 1999; Narsian and Patel, 2000). On the other hand soil microorganisms may had a considerable effect on the decrease of available $\mathrm{P}$ after the addition of $P$ fertilizers to soil.

Phosphorus is added in the form of phosphatidic fertilizers, part of which is utilized by plants and the remainder converted in to soluble fixed forms (Narsian and Patel, 2000). The sorption of phosphate by soil constituents controls the mobility and bioavailability of $\mathrm{P}$ in the soil- solution- plant systems (Barrow, 1999). The principal sorption mechanism is ligand exchange involving the formation of inner- sphere surface complexes. Thus, $\mathrm{P}$ deficiencies often occur in highly weathered acid soils. (Goldberg et al., 2008).

Chemical reactions in soil, including anion sorption from aqueous solutions, occur on a millisecond time scale (Sparks, 1999). Since sorption kinetics have a controlling influence on anion mobility, transport, and bioavailability, their assessment is a prerequisite for the efficient application of $\mathrm{P}$ fertilizers. Various models have been used to describe the kinetics for the sorption of phosphate by soils and soil constituents (Chien and Clayton, 1980; Aharoni et al., 1991; Frees et al., 1995). Many workers have shown that phosphate in soil are strongly sorbed to, and associated with, $\mathrm{Al}-$ and Fe- oxides. Being rich in free Aland Fe- oxides (and allophone), generally have a high capacity for sorbing phosphate (Garcia- Rodeja and GilSotres, 1997; Goldberg et al., 2008).

The reaction of $\mathrm{P}$ with soils is not instantaneous. The first stage proceeds relatively rapidly and this is followed by a slower sorption phase which continues for a long time. An equilibrium state may or may not be reached. Observed differences in the time needed to reach equilibrium have been attributed to differences in the chemical composition and physical morphology of the different soils and minerals (Chen et al., 1973). Accordingly, we have investigated the long-term sorption kinetics of $\mathrm{P}$ on two different types of soil. The study of sorption kinetics describes the adsorbate uptake rate and evidently this rate controls the residence time of adsorbate at the solid liquid interface (Sparks, 1989). The kinetics of $\mathrm{P}$ ion sorption on the two types of soil samples was analyzed using different kinetic models. The effect of soil sterilization and temperature on the kinetic parameters for the decrease available $P$ in the soils was investigated.

The objectives of this study are to characterize sorption behavior of $\mathrm{P}$ on two different types of soil, and to determine the importance of soil biological activity and temperature on $\mathrm{P}$ availability in soil. Information obtained from this study will give insights to soil scientists and agricultural engineers that may lead to improved soil fertilization strategies, disposal practices, and risk assessments. 


\section{MATERIALS AND METHODS}

\section{Soil sampling and analysis}

Compound surface $(0-30 \mathrm{~cm})$ soils were sampled from Guilan and Hamedan provinces in north and west north of Iran with temperate and semiarid climates, respectively. Each of compound soil sample was taken from five different sites in each land and mixed completely and analyzed as a soil sample. Four Guilan soil samples were taken one from rice and tea lands, and two from deciduous forests in three replicates. Four Hamedan soil samples were taken from vegetable and crop lands and deciduous and coniferous forests in three replicates.

Air- dried soil was subsequently crushed and sieved to pass a 2-mm mesh screen for particle-size analysis using the hydrometer method (Gee and Bauder, 1986). Calcium carbonate equivalents (CCE) were measured by back titration procedure (Loeppert and Suarez, 1996). Soil $\mathrm{pH}$ and electrical conductivity (EC) were measured in a 1:2 soil: water extract after shaking for 30 min (Jackson, 1958). Organic carbon (OC) was analyzed by dichromate oxidation and titration with ferrous ammonium sulfate (Walkley and Black, 1934). Cation- exchange capacity (CEC) and available $\mathrm{K}$ were measured according to Bower et al., (1952). Available phosphorus was extracted with $0.5 \mathrm{M} \mathrm{NaHCO}_{3}$ (pH 8.5) and determined spectrophotometrically as blue molybdate- phosphate complexes under partial reduction with ascorbic acid (Jackson, 1958). Amorphous Fe and Al by ammonium oxalate method and crystalline $\mathrm{Fe}$ and $\mathrm{Al}$ by dithionate- citrate method were extracted and measured by atomic absorption spectrometer on a Varian 220 instrument using an airacetylene flame (Loeppert, 1996).
Fresh soil samples were stored at $4^{\circ} \mathrm{C}$ for microbiological analyses. Basal respiration was measured as $\mathrm{CO}_{2}$ evolved in 5 days (Alef and Nannipieri, 1995). Substrate induced respiration was determined in $72 \mathrm{~h}$ (Alef and Nannipieri, 1995). Heterotrophic bacteria and fungi populations were estimated by plate count method (Alef and Nannipieri, 1995). Soil suspension and dilutions were prepared. Media of nutrient agar (NA), rose Bengal starch casein nitrate agar (RBSCNA) and modified potato dextrose agar (MPDA) were prepared in lab and used for determination of total soil bacterial, actinomycetes and fungi populations respectively (Alef and Nannipieri, 1995). Phosphorus solublizing bacteria were counted on a medium with low soluble $\mathrm{P}$ (three-calcium phosphate) medium (Sundara Rao and Sinha, 1963). Sample acid and alkaline phosphatases were analyzed according to the methods of Eivazi and Tabatabai (1977).

\section{Treatments of soil samples}

A part of soil samples were sterilized by autoclaving (Iran-teb Zaim, Product number: 1663$)$ at $121^{\circ} \mathrm{C}$ and 1.5 atmospheres for 30 minutes. The availability of $\mathrm{P}$ in soil samples was studied in two (sterile and unsterile) conditions after the addition of $400 \mathrm{mg} \mathrm{P}$ $\mathrm{kg}^{-1}$ soil, which was applied as $\mathrm{KH}_{2} \mathrm{PO}_{4}$. The salt of $\mathrm{KH}_{2} \mathrm{PO}_{4}$ dissolved in distilled water and sprayed on soils. The treated soils were uniformly wetted with a spray to a water content corresponding to the water retained at a matric potential of $300 \mathrm{hPa}$. This potential was known to reflect field capacity (FC) for the soils considered (Oyedele and Aina, 1989). The volume required to bring each of the soils to field capacity was determined from the difference in water content of an air-dry sample and a sample drained 
(following saturation) to $-300 \mathrm{hPa}$ matric potential. The treated and moistened soils were incubated up to $2880 \mathrm{~h}$ at 15 and 28 ${ }^{0} \mathrm{C}$ in 3 replicates. Separate batches were taken after $0.16,0.5,1,3,12,24,48,168$, $336,720,1440,2160$, and $2880 \mathrm{~h}$ for extraction with $0.5 \mathrm{M} \mathrm{NaHCO}$. The sterility of batches was checked for soil incubated in sterile condition prior to initiating experiment. Available phosphorus was determined spectrophotometrically as blue molybdatephosphate complexes under partial reduction with ascorbic acid (Jackson, 1958). Data were reported on soil dry weight basis $\left(\mathrm{mg} \mathrm{kg}^{-1}\right)$. The first order, second order, Elovich equation, mass transfer and power function kinetic models were tested by least- square regression analysis on $\mathrm{P}$ sorption data for Hamadan and Guilan soils incubated in sterile and unsterile conditions at 15 and $28{ }^{\circ} \mathrm{C}$ to determine which equation is the best according to the determination coefficients $\left(\mathrm{R}^{2}\right)$ and the standard errors of the estimate (St. E. Est.).

\section{Kinetic Modeling}

The decreased kinetics of $\mathrm{NaHCO}_{3}$ extractable $\mathrm{P}$ on two types of soil samples was analyzed using different kinetic models, these include: the first order, second order, Elovich, mass transfer and the power function equations (Sparks 1989; Aharoni et al, 1991 and Qadeer and Akhtar, 2005).

\section{The first order Equation}

The first order equation is generally expressed as (Sparks, 1989):

$\mathrm{d}\left(\mathrm{P}_{\mathrm{t}}\right) / \mathrm{dt}=\mathrm{k}_{1} \cdot\left(\mathrm{P}_{\mathrm{t}}\right)$

Where $\mathrm{P}$ is the $\mathrm{NaHCO}_{3}$-extractable $\mathrm{P}$ at time $\mathrm{t}\left(\mathrm{mg} \mathrm{kg}^{-1}\right)$ and $\mathrm{k}_{1}$ is the rate constant of first order sorption $\left(\mathrm{h}^{-1}\right)$. After integration and applying boundary conditions $\mathrm{t}=0$ to $\mathrm{t}=\mathrm{t}$ and $\mathrm{P}_{\mathrm{t}}=\mathrm{P}_{0}$ to $\mathrm{P}_{\mathrm{t}}=\mathrm{P}_{\mathrm{t}}$, the integrated form of equation (1) becomes:

$\operatorname{Ln}\left(\mathrm{P}_{\mathrm{t}}\right)=\operatorname{Ln}\left(\mathrm{P}_{0}\right)-\mathrm{k}_{1} \cdot \mathrm{t}$

When the values of $\ln \left(\mathrm{P}_{t}\right)$ were linearly correlated with $t$, the plot of $\ln \left(\mathrm{P}_{\mathrm{t}}\right)$ versus $\mathrm{t}$ will give a linear relationship from which $\mathrm{k}_{1}$ and $\mathrm{P}_{0}$ can be determined from the slope and intercept of the graph respectively.

\section{The Second Order Equation}

The second order chemisorptions kinetic equation is expressed as equation 3 (Sparks, 1989):

$\mathrm{d}\left(\mathrm{P}_{\mathrm{t}}\right) / \mathrm{d}_{\mathrm{t}}=\mathrm{k}_{2} \cdot\left(\mathrm{P}_{\mathrm{t}}\right)^{2}$

Where $\mathrm{P}_{t}$ is the $\mathrm{NaHCO}_{3}$-extractable $\mathrm{P}$ at time $\mathrm{t}\left(\mathrm{mg} \mathrm{kg}^{-1}\right)$ and $\mathrm{k}_{2}$ is the rate constant of the second order sorption $\left(\mathrm{g} \mathrm{mg}^{-1} \cdot \mathrm{h}^{-1}\right)$. For the boundary conditions $\mathrm{t}=0$ to $\mathrm{t}=\mathrm{t}$ and $\mathrm{P}_{\mathrm{t}}=\mathrm{P}_{0}$ to $\mathrm{P}_{\mathrm{t}}=\mathrm{P}_{\mathrm{t}}$ the integrated form of equation (3) becomes:

$1 /\left(\mathrm{P}_{\mathrm{t}}\right)=1 /\left(\mathrm{P}_{0}\right)+\mathrm{k}_{2} \cdot \mathrm{t}$

If the second order kinetics is applicable to the experimental data, the plot of $\left(\mathrm{P}_{\mathrm{t}}\right)^{-1}$ versus $t$ should give a linear relationship from which $\left(\mathrm{P}_{0}\right)$ and $\mathrm{k}_{2}$ can be determined from the slope and intercept of the plot respectively.

\section{The Elovich Kinetic Equation}

The Elovich equation is generally expressed as (Chien and Clayton, 1980):

$\mathrm{d}\left(\mathrm{P}_{\mathrm{t}}\right) / \mathrm{dt}=\alpha \mathrm{e}^{-\beta .(\mathrm{Pt})}$

Where $\mathrm{Pt}$ is the sorption capacity at time $\mathrm{t}$ $\left(\mathrm{mg} \mathrm{Kg}{ }^{-1}\right), \alpha$ is the initial adsorption rate $\left(\mu \mathrm{g} \mathrm{g}^{-1} \mathrm{~h}^{-1}\right.$ ) and, $\beta$ is the desorption constant ( $\mu \mathrm{g} \mathrm{g}^{-1} \mathrm{~h}^{-1}$ ) during any one experiment. 
To simplify the Elovich equation assumed $\alpha \beta \mathrm{t} \gg>1$ and by applying boundary conditions $\left(\mathrm{P}_{\mathrm{t}}\right)=\mathrm{P}_{0}$ at $\mathrm{t}=\mathrm{O}$ and $\left(\mathrm{P}_{\mathrm{t}}\right)=\left(\mathrm{P}_{\mathrm{t}}\right)$ at $\mathrm{t}=\mathrm{t}$, equation $(5)$ becomes:

$$
1 /\left(\mathrm{P}_{\mathrm{t}}\right)=1 / \beta \cdot \ln (\alpha \beta)+1 / \beta \cdot \ln \mathrm{t}
$$

Thus, if a plot of $1 /\left(\mathrm{P}_{\mathrm{t}}\right)$ versus $\operatorname{lnt}$ is linearly correlated, the constants $\alpha$ and $\beta$ can be computed from the slope and intercept of the graph.

\section{Mass Transfer Equation}

The mass transfer equation is generally expressed as (Sparks, 1989; Aharoni et al, 1991 and Qadeer and Akhtar, 2005):

$\left(\mathrm{P}_{0}\right)-\left(\mathrm{P}_{\mathrm{t}}\right)=\mathrm{D} \mathrm{e}^{(\mathrm{k} 0 \mathrm{t})}$

Where $\mathrm{P}_{0}$ is the initial $\mathrm{P}$ bioavailability $\left(\mathrm{mg} \mathrm{g}^{-1}\right), \mathrm{P}_{\mathrm{t}}$ is the $\mathrm{P}$ bioavailability at time $\mathrm{t}, \mathrm{t}$ is the incubation time $(\mathrm{h}), \mathrm{D}$ is a fitting parameter, $\mathrm{K}_{0}$ is the adsorption constant which is related to the mass transfer adsorption coefficient, $\mathrm{K}_{0}=\mathrm{KM}$, where $\mathrm{M}$ is the mass of the adsorbent $(\mathrm{g})$. A linearised form of equation (7) is:

$$
\operatorname{Ln}\left(\left(\mathrm{P}_{0}\right)-\left(\mathrm{P}_{\mathrm{t}}\right)\right)=\ln \mathrm{D}+\left(\mathrm{K}_{0} \mathrm{t}\right)
$$

If the sorption of phosphate ions on the adsorbent is depicted by the mass transfer model, then a plot of $\ln \left(\left(\mathrm{P}_{0}\right)-\left(\mathrm{P}_{\mathrm{t}}\right)\right)$ versus time should give a linear relationship from where the constants $\operatorname{lnD}$ and $\mathrm{K}_{0}$ can be determined from the slope and intercept of the plot respectively.

\section{The power function equation}

The power function equation is expressed as (Sparks, 1989; Aharoni et al, 1991 and Qadeer and Akhtar, 2005):

$(\mathrm{Pt})=\mathrm{at}^{\mathrm{b}}$

Where $P_{t}$ is the NaHCO3-extractable $P$ at time $\mathrm{t}\left(\mathrm{mg} \mathrm{g}^{-1}\right)$, $\mathrm{a}$ and $\mathrm{b}$ are equation constants. A linearised form of equation (9) is:

$\operatorname{Ln}\left(\mathrm{P}_{\mathrm{t}}\right)=\operatorname{lna}+\mathrm{blnt}$
Data statistically analyzed for standard deviation, means were calculated and Duncan's new multiple range test was made to assess soil properties differences. Statistical analyses and graphical works were performed on excel 2003 and MINITAB.

\section{RESULTS AND DISCUSSION}

\section{Soil properties}

The physical, chemical and biological properties of the soils used in this research are presented in Table 1. Sand, silt, clay, $\mathrm{pH}, \mathrm{EC}, \mathrm{OC}$, available $\mathrm{P}$, amorphous and crystalline $\mathrm{Fe}$ and $\mathrm{Al}$ contents and biological activities of soils sampled from temperate and semiarid regions were significantly different. Mean of sand, silt and clay contents in Hamedan soil samples were different from those in Guilan soils. Temperate soils samples had finer texture. However semiarid soils had higher $\mathrm{pH}, \mathrm{CCE}$ and available P. Also mean of amorphous and crystalline $\mathrm{Fe}$ and $\mathrm{Al}, \mathrm{EC}$, organic carbon, total bacteria, $\mathrm{P}$ solubilizing bacteria, basal respiration (BR), substrate induced respiration (SIR), acid and alkaline phosphatase activities in temperate soils were higher than those in semiarid soils (Table 1).

\section{Phosphorus sorption}

The temperate (Guilan) soils with high affinity surface sites for $\mathrm{P}$ sorption compared to semiarid (Hamedan) soils, had a lower $\mathrm{NaHCO}_{3}$-extractable $\mathrm{P}$ (Olsen- P) in each time of extraction (Figs 1 and 2). In semiarid soils compared to the temperate soils, the $\mathrm{P}$ added trough inorganic fertilizers was more available. Analysis of correlation coefficient between Olsen-extractable $\mathrm{P}$ and some soil properties at the end of incubation 
Effects of sterilization and temperature on soil P bioavailability, Safari et al.

Table 1. Some physical, chemical and biological properties of soils **.

\begin{tabular}{|c|c|c|c|c|c|c|c|c|c|c|}
\hline \multirow{2}{*}{ Soil property } & \multicolumn{5}{|c|}{ Guilan soil } & \multicolumn{5}{|c|}{ Hamadan soil } \\
\hline & 1 & 2 & 3 & 4 & mean & 5 & 6 & 7 & 8 & mean \\
\hline Sand (\%) & $23.6 \mathrm{e}$ & $37 \mathrm{c}$ & $15 \mathrm{f}$ & $16.6 \mathrm{ef}$ & 23.05 & $60.3 \mathrm{a}$ & $54.3 \mathrm{ab}$ & $27 \mathrm{~d}$ & $50.3 \mathrm{~b}$ & 47.98 \\
\hline Silt(\%) & $27.3 \mathrm{~b}$ & $29.3 \mathrm{~b}$ & $36.6 \mathrm{a}$ & $39 \mathrm{a}$ & 33.05 & $23 \mathrm{c}$ & $24.6 \mathrm{bc}$ & $40.66 \mathrm{a}$ & $26.6 \mathrm{~b}$ & 28.72 \\
\hline Clay(\%) & $46.3 \mathrm{a}$ & $33 \mathrm{~b}$ & $48.3 \mathrm{a}$ & $44.3 \mathrm{a}$ & 42.98 & $16.6 \mathrm{c}$ & $21 \mathrm{c}$ & $32.3 \mathrm{~b}$ & $20 \mathrm{c}$ & 22.48 \\
\hline $\mathrm{PH}$ & $7 \mathrm{~b}$ & $5.9 \mathrm{c}$ & $6.2 \mathrm{c}$ & $6.8 \mathrm{~b}$ & 6.48 & $7.86 \mathrm{a}$ & $7.8 \mathrm{a}$ & $7.83 \mathrm{a}$ & $8 \mathrm{a}$ & 7.873 \\
\hline $\mathrm{EC} \mathrm{dsm}{ }^{-1}$ & $2.06 \mathrm{a}$ & $0.32 \mathrm{~d}$ & $1.93 \mathrm{ab}$ & $1.8 \mathrm{~b}$ & 1.53 & $0.48 \mathrm{~cd}$ & $0.52 \mathrm{c}$ & $0.57 \mathrm{c}$ & $0.72 \mathrm{c}$ & 0.573 \\
\hline $\operatorname{ECC}^{\#}(\%)$ & $3.06 \mathrm{c}$ & $1.71 \mathrm{~d}$ & $3 \mathrm{dc}$ & $1.16 \mathrm{~d}$ & 2.23 & $13.3 \mathrm{~b}$ & $17 \mathrm{a}$ & $18.3 \mathrm{a}$ & $18.3 \mathrm{a}$ & 16.72 \\
\hline $\operatorname{CEC}\left(\mathrm{Cmolc} \mathrm{kg}^{-1}\right)$ & $25.3 \mathrm{~b}$ & $30 \mathrm{a}$ & $21 \mathrm{c}$ & $29.3 \mathrm{ab}$ & 26.4 & $9 \mathrm{e}$ & $19.6 \mathrm{~cd}$ & $18.3 \mathrm{~d}$ & $10 \mathrm{e}$ & 14.23 \\
\hline OC\# (\%) & $2.3 \mathrm{a}$ & $2.13 \mathrm{a}$ & $1.59 \mathrm{~b}$ & $1.46 \mathrm{~b}$ & 1.87 & $1.61 \mathrm{~b}$ & $0.92 \mathrm{~d}$ & $1.16 \mathrm{c}$ & $0.91 \mathrm{~d}$ & 1.15 \\
\hline Available $\mathrm{P}\left(\mathrm{mg} \mathrm{kg}^{-1}\right)$ & $11.6 \mathrm{~d}$ & $12.3 \mathrm{~d}$ & $5 \mathrm{e}$ & $5 \mathrm{e}$ & 8.49 & $60.3 \mathrm{a}$ & $17.3 \mathrm{c}$ & $32.3 \mathrm{~b}$ & $13.3 \mathrm{~d}$ & 30.8 \\
\hline Amorphous $\mathrm{Fe}\left(\mathrm{gkg}^{-1}\right)$ & $1.5 \mathrm{c}$ & $2.22 \mathrm{ab}$ & $1.86 \mathrm{~b}$ & $1.1 \mathrm{~d}$ & 1.67 & $2.52 \mathrm{a}$ & $0.48 \mathrm{f}$ & $0.86 \mathrm{e}$ & $0.73 \mathrm{e}$ & 1.15 \\
\hline Available $\mathrm{K}\left(\mathrm{mg} \mathrm{kg}^{-1}\right)$ & $256 \mathrm{c}$ & $266.6 \mathrm{c}$ & $145 \mathrm{~d}$ & $150 \mathrm{~d}$ & 204.4 & $286.6 \mathrm{~b}$ & $260 \mathrm{c}$ & $353.3 \mathrm{a}$ & $263.3 \mathrm{c}$ & 290.8 \\
\hline Crystalline $\mathrm{Fe}\left(\mathrm{gkg}^{-1}\right)$ & $25 \mathrm{~b}$ & $23.6 \mathrm{~b}$ & $42.01 \mathrm{a}$ & $18 \mathrm{c}$ & 27.15 & $7.35 \mathrm{e}$ & $13.9 \mathrm{~d}$ & $12.57 \mathrm{~d}$ & $24.43 \mathrm{~b}$ & 14.56 \\
\hline Amorphous $\mathrm{Al}\left(\mathrm{gkg}^{-1}\right)$ & $1.23 \mathrm{c}$ & $2.62 \mathrm{a}$ & $1.4 \mathrm{~b}$ & $1.03 \mathrm{~d}$ & 1.57 & $0.9 \mathrm{e}$ & $0.58 \mathrm{f}$ & $0.68 \mathrm{f}$ & $0.38 \mathrm{~g}$ & 0.635 \\
\hline Crystalline $\mathrm{Al}\left(\mathrm{gkg}^{-1}\right)$ & $4.53 \mathrm{~b}$ & $5.2 \mathrm{a}$ & $5.25 \mathrm{a}$ & $3.5 \mathrm{c}$ & 4.62 & $1.34 \mathrm{~g}$ & $2.03 \mathrm{~d}$ & $1.73 \mathrm{e}$ & $1.6 \mathrm{f}$ & 1.68 \\
\hline Bacteria* $10^{6}$ & $17 \mathrm{~d}$ & $21 \mathrm{c}$ & $23 \mathrm{a}$ & $22 \mathrm{~b}$ & 20 & $2 \mathrm{j}$ & $8 \mathrm{~g}$ & $4 \mathrm{i}$ & $12 \mathrm{e}$ & 6 \\
\hline Bacteria sloubilizing $\mathrm{P} * 10^{4}$ & $9 \mathrm{bc}$ & $17 \mathrm{a}$ & $16 \mathrm{a}$ & $9 \mathrm{bc}$ & 12 & $7 \mathrm{dc}$ & $18 \mathrm{a}$ & $2 \mathrm{e}$ & $11 \mathrm{~b}$ & 9 \\
\hline Fungi* $10^{3}$ & $32 \mathrm{c}$ & $22 \mathrm{~d}$ & $41 \mathrm{~b}$ & $17 \mathrm{~d}$ & 28 & $3 \mathrm{e}$ & $8 \mathrm{e}$ & $4 \mathrm{e}$ & $48 \mathrm{a}$ & 15 \\
\hline $\mathrm{BR}^{\#}\left(\mathrm{mg} \mathrm{CO} \mathrm{g}^{-1}\right.$ soil day $\left.{ }^{-1}\right)$ & $1.4 \mathrm{a}$ & $0.9 \mathrm{ab}$ & $0.82 \mathrm{~b}$ & $1 \mathrm{a}$ & 1.03 & $0.71 \mathrm{~b}$ & $0.7 \mathrm{~b}$ & $0.7 \mathrm{~b}$ & $0.86 \mathrm{ab}$ & 0.74 \\
\hline $\operatorname{SIR}^{\#}\left(\mathrm{mg} \mathrm{CO} \mathrm{g}^{-1}\right.$ soil day $\left.{ }^{-1}\right)$ & $1.6 \mathrm{~b}$ & $1.7 \mathrm{a}$ & $1.63 \mathrm{ab}$ & $1.43 \mathrm{c}$ & 1.59 & $1.25 \mathrm{~d}$ & $1.6 \mathrm{ab}$ & $1.06 \mathrm{c}$ & $1.46 \mathrm{c}$ & 1.34 \\
\hline Acid Phosphatase ( $\mu$ mol P.N.P soil $\mathrm{h}^{-1}$ ) & $53.2 \mathrm{~b}$ & $66.7 \mathrm{a}$ & $10.5 \mathrm{~d}$ & $26 \mathrm{c}$ & 39.1 & $4.13 \mathrm{~d}$ & $4.6 \mathrm{~d}$ & $4 \mathrm{~d}$ & $7.6 \mathrm{~d}$ & 5.08 \\
\hline Basic Phosphatase $\left(\mu\right.$ mol P.N.P soil $\left.\mathrm{h}^{-1}\right)$ & $9.5 \mathrm{ef}$ & $33.5 \mathrm{a}$ & $16.8 \mathrm{bc}$ & $8.3 \mathrm{gf}$ & 17.02 & $7 \mathrm{~g}$ & $13.6 \mathrm{~d}$ & $1.8 \mathrm{~h}$ & $17.2 \mathrm{~b}$ & 9.9 \\
\hline
\end{tabular}

\#ECC-Equivalent carbonate calcium, OC- dichromate (oxidable) organic carbon, BR-Basal respiration, SIR-Substrate induced respiration.

**Means followed by the same letter in each row are not significantly different $(p<0.05)$. 
(2880 h) showed that (semiarid) soils with higher sand, $\mathrm{CCE}$ and $\mathrm{pH}$ and with lower clay, CEC, EC, OC, amorphous and crystalline $\mathrm{Al}$ had higher $\mathrm{NaHCO}_{3}$ extractable P (Table 2).

Table 2. Pearson correlation coefficient between available $\mathrm{P}$ and some properties at the end of incubation*.

\begin{tabular}{lc}
\hline Soil property & Available P \\
\hline Sand & $0.78^{* *}$ \\
Silt & -0.5 \\
Clay & $-0.69^{*}$ \\
pH & $0.67 *$ \\
EC & -0.25 \\
ECC & $0.78^{* *}$ \\
OC & $-0.72^{*}$ \\
Amorphous Fe & -0.08 \\
Crystalline Fe & $-0.67 *$ \\
Amorphous Al & -0.45 \\
Crystalline Al & $-0.73^{*}$ \\
\hline
\end{tabular}

*Correlation coefficients marked by * and ** are significant at the 0.05 and 0.01 level respectively (2-tailed).

**OC- dichromate (oxidable) organic carbon, ECC- Equivalent carbonate calcium.

Erika et al. (2009) observed that the content of free $\mathrm{Fe}$ and $\mathrm{Al}$ oxides appears to be the principal factor affecting the rate and capacity of phosphate sorption by soils. Also in the case of phosphate on the other hand, the content of allophone, Alhumus and Fe-humus complexes that has a controlling influence on sorption and release. Many workers have shown that phosphate in soil are strongly sorbed to, and associated with, Al- and Fe- oxides (Freese et al., 1995). Temperate or Guilan soils with high contents of free $\mathrm{Al}-$ and $\mathrm{Fe}-$ oxides and allophane, generally have a high capacity for sorbing phosphate.
Phosphorus sorption by soils in all treatments occurred in two stages (Figures 1 and 2). The first stage involved rapid $P$ uptake. It was completed within 4 days. A slower removal stage followed, which in some cases continued for many months. Thus, contact time is an important determination of the extent of $\mathrm{P}$ sorption when a solution is contacted with a sorbent material. The fast reaction period was similar to that observed for $\alpha-\mathrm{Al}_{2} \mathrm{O}_{3}$ (24h) (Chen et al., 1973) and $\mathrm{Fe}(\mathrm{OH})_{3}$ and $\mathrm{Al}(\mathrm{OH})_{3}(10 \mathrm{~h})$ (Bolan, et al.,1985). However, the period was longer than that observed for $\gamma$-FeOOH and $\alpha-\mathrm{Fe}_{2} \mathrm{O}_{3}$ (5$10 \mathrm{~min}$ ) (Madrid and De Arambarri, 1985), clay minerals such as kaolinite, montmorilonit and illite $(4 \mathrm{~h})$ (Edzwald, et al., 1976) , and $\mathrm{CaCO}_{3}(10 \mathrm{~s})$ (Kuo and Lotse, 1972) and (10 min) (Griffin and Jurinak 1973). The prolonged persistence of $\mathrm{P}$ sorption has been attributed to the precipitation of $\mathrm{P}$ or penetration and absorption of $\mathrm{P}$ in pores of particles or aggregates (Chen et al., 1973; Madrid and De Arambarri, 1985). Slow precipitation of $\mathrm{P}$ can occur as $\mathrm{Al}$ and $\mathrm{Fe}$ ions are gradually released through dissolution. Alternatively, diffusion of $\mathrm{PO}_{4}{ }^{3-}$ from solution in to pores may lead to precipitation with $\mathrm{Fe}$ and $\mathrm{Al}$ ions present. For calcareous soils, crystalline transformation of initial amorphous precipitates has also been proposed to explain the occurrence of the slow sorption reaction (Novak et al., 1979).

The first step of P sorption in soils was higher in unsterile condition compared to that in sterile condition. It may be related to microbial $\mathrm{P}$ absorption and adsorption in unsterile soils. After the first step of $\mathrm{P}$ sorption, available P decreased continuously in sterile soils. In contrast, it increased in unsterile soils after 20 and 30 days (around 400 to 800 hours) due soil microbial activity (Fig 1). The $\mathrm{NaHCO}_{3}$ extractable $\mathrm{P}$ was greater in unsterile soils compared to sterile soils may be due to 


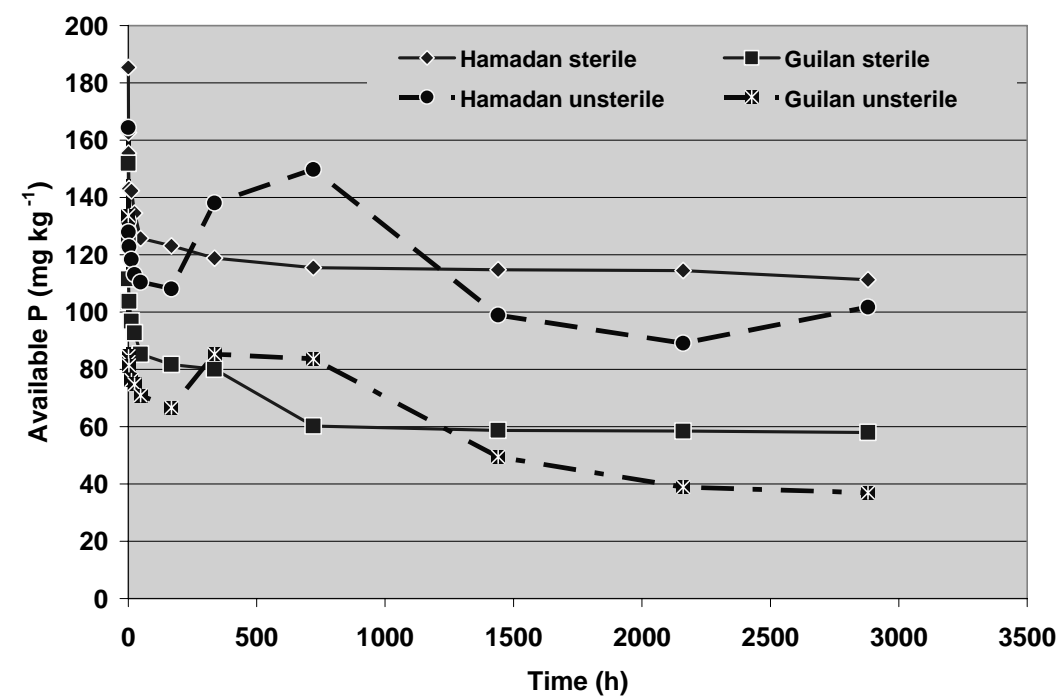

Figure 1. The effects of sterilization on available $\mathrm{P}$ in two different soil types incubated at $28^{\circ} \mathrm{C}$.

activities of phosphate solubilizing microorganisms in these days. Some of soil microorganisms posses mineral phosphate solubilizing activities. This ability is generally associated to the release of organic acids (such as $\alpha$-keto glucorunic acid), and decreasing the $\mathrm{pH}$ (Motsara et al., 1995). Moreover, these organic acids can considerably increase the concentration of $\mathrm{P}$ in the soil solution through the chelation of $\mathrm{Ca}, \mathrm{Fe}$ and $\mathrm{Al}$, change reactions and solubilization of low soluble salts (such as apatite and octacalcium phosphate in calcareous soils, and varisite and sterngite in acid soils) (Gadd, 1999). Microbial solubilization of poorly soluble mineral phosphates in soil is an important process in natural ecosystems and in agricultural soils.

After 30 days of soil incubation in FC and $28{ }^{\circ} \mathrm{C}$, available $\mathrm{P}$ concentration reached an equilibrium point in soils incubated in sterile condition. However available $\mathrm{P}$ concentration fluctuated in unsterile soils due to microbial activities such as adsorption, absorption, solubilization, and mineralization of inorganic and organic $\mathrm{P}$ in soil (Figure 1).

It was reported that equilibrium was reached after 42 days of contact in the case of some soils with low $\mathrm{NaHCO}_{3}-$ extractable $\mathrm{P}$ of $<10 \mu \mathrm{g} \mathrm{g}^{-1}$, while others with higher $\mathrm{NaHCO}_{3}$ - extractable $\mathrm{P}>10$ $\mu \mathrm{g} \mathrm{g}^{-1}$ reached equilibrium after only 3 days. Griffin and Jurinak (1973) observed that the concentration of solution $\mathrm{P}$ remained constant for calcite after contact for 10-20 $\mathrm{min}$ while Kuo and Lotse (1972) reported equilibration after only 15 s. Phosphorus concentrations in solution have been shown to decrease for up to 30 days when in contact with oxides and hydroxides of $\mathrm{Fe}$ and for up to 60 days with Al oxide (Prafitt, 1989; Chen et al., 1973). In our study in sterile soils $P$ availability remained constant after 30 days of soil incubation in FC. Fe and $\mathrm{Al}$ hydrous oxides, particularly those with 
(A)

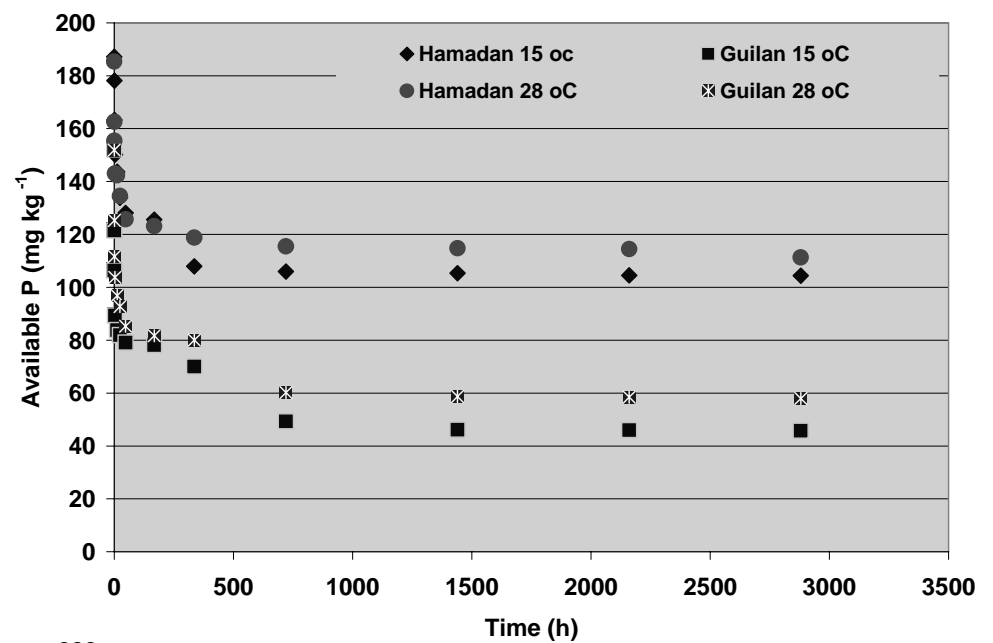

(B)

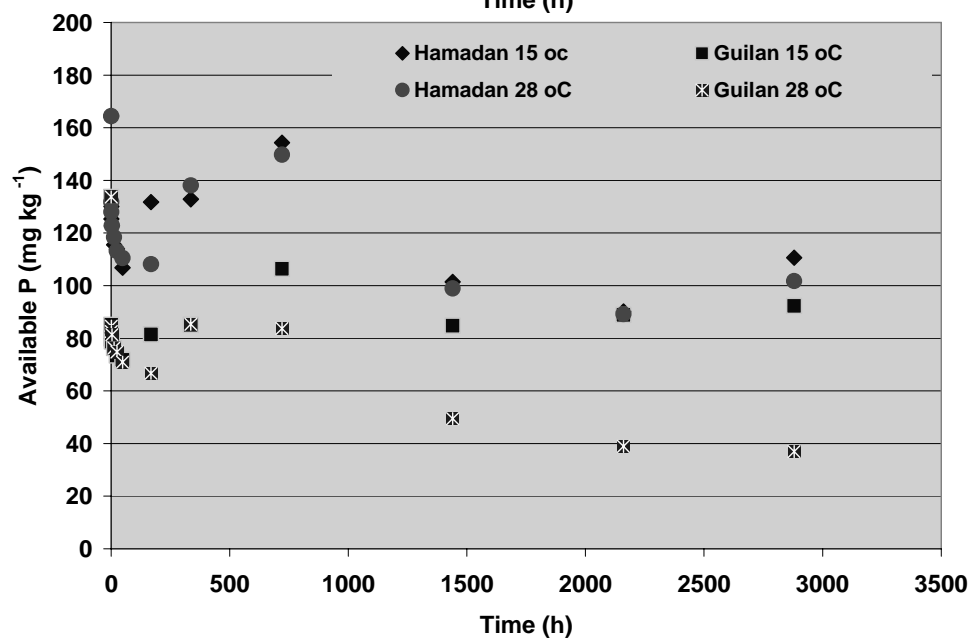

Figure 2. The effects of temperature on available $\mathrm{P}$ in two different soil types (A) in the sterile condition and (B) in the unsterile condition.

short-range order (amorphous), are believed to govern $\mathrm{P}$ sorption in soils. Surface sorption by $\mathrm{CaCO}_{3}$ in calcareous soils has been found to be at least partly responsible (Ryden, et al., 1985). The prolonged persistence of $\mathrm{P}$ sorption has been attributed to the precipitation of $\mathrm{P}$ or penetration of $\mathrm{P}$ in pores of particles (Chen et al., 1973).
Despite that the analysis of variance did not show any significant difference between $\mathrm{NaHCO}_{3}$ - extractable $\mathrm{P}$ in soils incubated in two temperatures (data has not reported here), data represented in Figure 2A showed that in sterile condition available $\mathrm{P}$ was higher in soils incubated at $28^{\circ} \mathrm{C}$ compared to that in soils incubated at $15^{\circ} \mathrm{C}$. However this result 
was reverse in unsterile condition especially for temperate soils (Figure 2B). Available $\mathrm{P}$ was higher in temperate unsterile soils incubated at $28^{\circ} \mathrm{C}$ compared to that in soils incubated at $15^{\circ} \mathrm{C}$ (Figure 2B).

\section{Kinetic of Phosphorus sorption}

Since sorption kinetics has a controlling influence on anion mobility, transport and bioavailability, their assessments is a prerequisite for the efficient application of P fertilizers (Sparks, 1999). The soil sterilization had significant effect on the suitability of kinetic models (Tables 3 and 4). The first order equation, second order equation, Elovich kinetic equation and power function equation were suitable for description of the adsorptive/ precipitate process of $\mathrm{P}$ in semiarid sterile soils incubated at 15 and $28^{\circ} \mathrm{C}$. The mass transfer equation was not suitable for these data because of insignificant $\mathrm{R}^{2}$ and high standard errors of the estimate (St. E. Est.). The best equation was Elovich kinetic model due to its higher determination coefficients and lower standard errors of the estimate. The second order, power function and first order equations were also suitable for data of available $\mathrm{P}$ obtained from semiarid unsterile soils incubated at $28^{\circ} \mathrm{C}$. However among the tested models only the second order equation was suitable for data of available $\mathrm{P}$ obtained from semiarid unsterile soils incubated at $15^{\circ} \mathrm{C}$.

The first order equation, second order equation, Elovich kinetic equation, mass transfer equation and power function equation were suitable for description of the adsorptive/ precipitate process of $\mathrm{P}$ in temperate sterile soils incubated at 15 and $28^{\circ} \mathrm{C}$. Similar to the result for semiarid soils, the best equations for the decrease kinetic of available $\mathrm{P}$ were the second order and Elovich kinetic models due to their higher determination coefficients and lower standard errors of the estimate. These equations were also suitable for data of available $\mathrm{P}$ obtained from temperate unsterile soils incubated at $28^{\circ} \mathrm{C}$. However none of the tested kinetic equation was suitable for data of available $\mathrm{P}$ obtained from temperate unsterile soils incubated at $15^{\circ} \mathrm{C}$ may be due to microbial effects on available $\mathrm{P}$ fluctuation in unsterile soils.

So, the effect of microbial activities in unsterile soils on the kinetic parameters for the decrease of $\mathrm{NaHCO}_{3}$ - extractable $\mathrm{P}$ in soil was significant. In semiarid and temperate soils all of the evaluated equations could not describe the adsorptive process of $\mathrm{P}$ in unsterile condition at $15^{\circ} \mathrm{C}$. However the effect of incubation temperature on the kinetic parameters for the decrease of $\mathrm{NaHCO}_{3}$ extractable $\mathrm{P}$ in both unsterile soils compared with sterile soils was significant. Soil incubation at higher temperature in unsterile condition could improve the determination coefficients and the standard error of the estimates for the equations. This implies that the experimental design should be dictated by what would give a better outcome of the model.

\section{CONCLUSION}

Results showed that the decrease rate of $\mathrm{P}$ bioavailability depend strongly on soil properties and then soil sterilization. The temperate soils with high affinity surface sites for $\mathrm{P}$ sorption compared to semiarid soils, had a lower $\mathrm{NaHCO}_{3}$-extractable P in each time of extraction. The decrease rate of phosphorus bioavailability was considerably higher in sterile soil compared to unsterile soils in 20 days of soil incubation. Before and after that the decrease rate of phosphorus bioavailability was higher in unsterile soil 
J. Soil Sci. Plant Nutr. 11 (2): 109- 122 (2011)

Table 3. The determination coefficients (R2), y intercept (A), slop (B) and the standard errors of the estimate (St. E. Est.) for linearized form of some kinetic equations for Hamadan soils in sterile and unsterile conditions.

\begin{tabular}{|c|c|c|c|c|c|c|c|c|}
\hline \multirow{2}{*}{ Kinetic model } & \multicolumn{4}{|c|}{ Sterile condition } & \multicolumn{4}{|c|}{ Unsterile condition } \\
\hline & $\mathbf{R}^{2}$ & A & B & St.E.Est ${ }^{\mathrm{a}}$ & $\mathbf{R}^{2}$ & A & B & St.E.Est ${ }^{a}$ \\
\hline \multicolumn{9}{|l|}{ For $15^{\circ} \mathrm{C}$ data } \\
\hline The first order equation & $0.48^{*}$ & 4.96 & -0.0001 & .1 & 0.26 & 4.85 & -0.00008 & 0.1 \\
\hline The second order equation & $0.53^{* *}$ & 0.007 & 0.00001 & 0.0007 & $0.32 *$ & 0.007 & 0.00001 & 0.0008 \\
\hline The Elovich Kinetic equation & $0.96^{* *}$ & 0.006 & 0.0004 & 0.0001 & .025 & 0.007 & 0.0002 & 0.0004 \\
\hline Mass transfer equation & 0.28 & 3.84 & 0.0003 & 0.4 & 0.17 & 4.2 & 0.0001 & 0.2 \\
\hline The power function equation & $0.98^{* *}$ & 5 & -0.06 & 0.01 & 0.25 & 4.89 & -0.025 & 0.05 \\
\hline \multicolumn{9}{|l|}{ For $28^{\circ} \mathrm{C}$ data } \\
\hline The first order equation & $0.37^{*}$ & 4.94 & -0.0001 & 0.1 & $0.33^{*}$ & 4.83 & -0.0001 & 0.1 \\
\hline The second order equation & $0.46^{*}$ & 0.007 & 0.00001 & 0.0006 & $0.39^{*}$ & 0.0078 & 0.00001 & 0.0008 \\
\hline The Elovich Kinetic equation & $0.97^{* *}$ & 0.006 & 0.0003 & 0.00008 & $0.39 *$ & 0.0074 & 0.0002 & 0.0004 \\
\hline Mass transfer equation & 0.23 & 3.94 & 0.0002 & 0.3 & 0.21 & 4.24 & 0.0001 & 0.2 \\
\hline The power function equation & $0.93^{* *}$ & 5.06 & -0.04 & 0.02 & $0.33 *$ & 4.88 & -0.02 & 0.05 \\
\hline
\end{tabular}

a) St.E.Est- The standard error of the estimate

*determination coefficient is significant at the 0.05 level.

** determination coefficient is significant at the 0.01 level. 
Effects of sterilization and temperature on soil P bioavailability, Safari et al.

Table 4. The determination coefficients (R2), y intercept (A), slop (B) and the standard errors of the estimate (St. E. Est.) for linearized form of some kinetic equations for Guilan soils in sterile and unsterile conditions.

\begin{tabular}{|c|c|c|c|c|c|c|c|c|}
\hline \multirow{2}{*}{ Kinetic model } & \multicolumn{4}{|c|}{ Sterile condition } & \multicolumn{4}{|c|}{ Unsterile condition } \\
\hline & $\mathbf{R}^{2}$ & A & B & St.E.Est ${ }^{\mathrm{a}}$ & $\mathbf{R}^{2}$ & A & B & St.E.Est ${ }^{a}$ \\
\hline \multicolumn{9}{|l|}{ For $15^{\circ} \mathrm{C}$ data } \\
\hline The first order equation & $0.62^{* *}$ & 4.51 & -0.0003 & 0.18 & 0.03 & 4.43 & 0.00003 & 0.12 \\
\hline The second order equation & $0.72^{* *}$ & 0.01 & 0.00005 & 0.002 & 0.08 & 0.011 & 0 & 0.001 \\
\hline The Elovich Kinetic equation & $0.86^{* *}$ & 0.0083 & 0.0014 & 0.008 & 0.1 & 0.01 & 0.0001 & 0.0009 \\
\hline Mass transfer equation & $0.33^{*}$ & 4.61 & 0.0001 & 0.2 & 0.4 & 4.71 & -0.0001 & 0.13 \\
\hline The power function equation & $0.93^{* *}$ & 4.73 & -0.11 & 0.04 & 0.01 & 4.46 & -0.006 & 0.09 \\
\hline \multicolumn{9}{|l|}{ For $28^{\circ} \mathrm{C}$ data } \\
\hline The first order equation & $0.58^{* *}$ & 4.59 & -0.00002 & 0.07 & $0.74^{* *}$ & 4.4 & -0.0003 & 0.13 \\
\hline The second order equation & $0.71^{* *}$ & 0.009 & 0.00003 & 0.0006 & $0.85^{* *}$ & 0.01 & -0.00006 & 0.001 \\
\hline The Elovich Kinetic equation & $0.9^{* *}$ & 0.008 & 0.001 & 0.0005 & $0.53^{* *}$ & 0.009 & 0.0012 & 0.001 \\
\hline Mass transfer equation & $0.37^{*}$ & 4.53 & 0.0002 & 0.08 & $0.4^{*}$ & 4.72 & 0.0001 & 0.13 \\
\hline The power function equation & $0.95^{* *}$ & 4.79 & -0.09 & 0.02 & $0.6^{* *}$ & 4.56 & -0.08 & 0.09 \\
\hline
\end{tabular}

a) St.E.Est- The standard error of the estimate

* determination coefficient is significant at the 0.05 level.

** Determination coefficient is significant at the 0.01 level. 
compared to sterile soils. The effect of soil sterilization may be due to absorption and adsorption of available $\mathrm{P}$ and on the other hand to solubilization and release of available $\mathrm{P}$ by soil microorganisms. Phosphorus physical and chemical sorption by the solid adsorbents was rapid in the initial step and it was complete within 4 days. The initial fast reaction has been mainly attributed to sorption on mineral surfaces. After 30 days, available $P$ remained constant in soils incubated in sterile condition.

However in unsterile soils after initial rapid decrease of available $\mathrm{P}$, it fluctuated during 120 days of soil incubation. After 20 days of soil incubation the amount of $\mathrm{NaHCO}_{3}$ - extractable $\mathrm{P}$ increased. This increase may be due to phosphatesolubilizing microorganisms (PSM).

This study also showed that the Elovich kinetic models were better choice to express the decrease kinetic of $\mathrm{NaHCO}_{3}$-extractable $\mathrm{P}$ according to its higher determination coefficient and the small standard error of estimate. However in unsterile soils incubated at $15^{\circ} \mathrm{C}$ the suitability of the tested equations decreased considerably may be due to $\mathrm{P}$ fluctuation and importance of biological process compared to physical and chemical processes in $\mathrm{P}$ availability in soils.

In a short-term study it may be concluded that the availability of $\mathrm{P}$ depends strongly on soil physical and chemical processes, but after 20 days soil biological processes play an important role in $\mathrm{P}$ availability in unsterile soil. So the suitability of kinetic models for expression of $\mathrm{P}$ availability strongly depends on the soil biological processes emerging after 20 days of soil incubation.

\section{REFERENCES}

Aharoni, C., Sparks, D., Levinson, L., Raviana, J., 1991. Kinetics of soil chemical reaction. Relationships between empirical equation and diffusion models. Soil Sci Soc Am J. 55, 1307-1312.

Alef, K. Nannipieri, P. 1995. Methods in applied soil microbiology and biochemistry, Academic Press, Harcourt Brace and Company, Publishers, London.

Barrow, N.J. 1999. The four laws of soil chemistry, The leeper lecture 1998. Austr. J. Soil Res. 37, 787-829.

Bower, C.A., Reitmeir, R.F., Fireman, M. 1952. Exchangeable cation analysis of saline and alkali soils. Soil Sci 73: 251-261.

Chen, Y.S.R., Butier, J.N., Stumm, W. 1973. Kinetic study of phosphate reaction with aluminium oxide and kaolinite. Environ. Sci .Technol. 7, 327-332.

Chien, S.H., Clayton, W.R. 1980. Application of Elovich equation to the kinetics of phosphate release and sorption in soils. Soil. Sci.Soc. Am. J. $44,265-268$

Edzwald, J.K., Toensing, D.C., Leung, M.C.Y. 1976. Phosphate adsorption reaction with clay minerals. Environ. Sci. Technol. 10, 485-490.

Eivazi, F., Tabatabai, M.A. 1977. Phosphatase in soils. Soil Biol. Biochem. 9: 167-172.

Freese, D., Van Riemsdijk, W.H., Vander Zee, S. 1995. Modeling phosphate sorption kinetics in acid soils. Eur. J. Soil Sci. 46, 239-245.

Garcia-Rodeja, I., Gil-Sotres, F. 1997 Prediction of parameters describing phosphorusdesorption kinetics in soils of Galicia (Northwest Spain). J. Environ. Qual. 26, 1363-1369.

Gadd, G.M. 1999. Fungal production of citric and oxalic acid, Importance in metal speciation, physiology and biogeochemical processes. Adv. Microb. Physiol. 4, 47-92. 
Gee, G.W., Bauder, J.W. 1986. Particle size analysis. In, Klute A.(ed),. Method of soil analysis, part I, Physical and mineralogical methods, Soil Science Society of America, Madison, Wisconsin USA. 383-411.

Goldberg, S., Scalera, E., Adamo. P. 2008. Molybdenum adsorption by volcanic Italian soils. Commun. Soil Sci. Plant Anal. 39:693Y706.

Griffin, R.A., Jurinak, J.J. 1973. Kinetics of the phosphate interaction with calcite. Soil Sci. Soc. Am. Proc. 38, 75-79.

Jackson, M.L. 1958. Soil chemical Analysis. Prentice Hall, Englewood Cliffs, NJ.

Khan, M.S., Zaidi A. Wani, P.A. 2007. Role of phosphate - solubilizing microorganisms in sustainable agriculture- A review. Agron. Sustain. Dev, 27, 29-43.

Kuo, S., Lotse, E.G. 1972. Kinetics of phosphate adsorption by calcium carbonate and $\mathrm{Ca}$ Kaolinite. Soil Sci. Soc. Am. Proc. 36, 725-729.

Loeppert, R.H., Suarez, G.L. 1996. Carbonates and Gypsum. In, Sparks D.L.(ed). Methods of soil analysis. Part 3, Chemical methods. Madison, Wisconsin, USA.

Loeppert, R.H. 1996. Iron. In: Sparks, D. L (ed.). Methods of soil Analysis. Madison, Wisconsin, SSSA. pp. 639-664.

Madrid, L,. De Arambarri, P. 1985. Adsorption of phosphate by two iron oxides in relation to their porosity. J. Soil. Sci. 36, 523-530.

Motsara, M.R., Bhattacharyya P.B. Srivastara, B. 1995. Biofertilizers-their description and characteristics In, Biofertilizers Technology, Markting and Usage. A source book- cum- Glossary. Fertilizer development and consultation organization 204-204 ABhanot Corner, 1-2 Pamposh Enclare, New Delhi,110048, India,PP, 9-18.

Narsian, V., Patel. H.H. 2000. Aspergillus aculeatus as rock phosphate solubilizers. Soil Biol. Biochem., 32, 559-565

Novak, L.T., Petschauer, F.J. 1979. Kinetics of the reaction between orthophosphate ions and Muskegon dune sand. J. Environ. Qual. 8, 312318.
Oyedele D.J., Aina, P.O. 1989. Erosion characteristics of selected southwestern Nigerian soils in relation to physicochemical properties, overland flow and chemical conditioning. Ife J. Agric. II(1)(2): 1-10.

Ozgonen, H., Bicici, M., Erkilic, A. 1999. The effect of salicylic acid and endomycorrhizal fungus $\mathrm{G}$. intravadices on plant development of tomato and Fusarium with caused by Fusarium oxysporum f. sp. lycopersici. Turk. J. Agric. For. 25, 25-29.

Qadeer, R., Akhtar, S. 2005. Kinetics Study of Lead Ion Adsorption on Active Carbon. Turk. J. Chem. 29: 95-99.

Ryden, J.C., Curtin, D., Cheema, M.A. 1985. Significance of iron oxides and calcium carbonate particle size in phosphate sorption by calcareous soils. Soil Sci. Soc. Am. J. 48, 74-76.

Sparks, D.L. 1999. Kinetics of soil chemical processes. San Diego, CA, Academic Press, Inc.

Sparks, D.L. 1989. Kinetics of Soil Chemical Processes. Academic press. San Diego., Ca, USA.

Sundara Rao, W.V.B., Sinha, M.K. 1963. Phosphate dissolving organisms in the soil and rhizosphere. Ind. J. Agric. Sci. 33

Tilak, K.V.B.R., Ranganayak, N., Pal, K.K., De, R., Saxena, A.K., Nautiyal, C.S., Mittal, S., Tripathi, A.K., Johri, B.N. 2005. Diversity of plant growth and soil health supporting bacteria. Curr. Sci. 89, 136-150.

Walkley, A., Black, I.A. 1934. An examination of the Degtareff method for determining soil organic matter, and a proposed modification of the chromic acid titration method. Soil Sci. 37, 29-38.

Whitelaw, M.A., Harden, T.J., Helyar, K.R 1999. Phosphate solubilization in solution culture by the soil fungus Penicillium radicum. Soil Brol. Biochem. 31, 655-665.

Yahya, A.I., Al-Azawi, S.K. 1989. Occurrence of phosphate-solubilizing bacteria in some Iraqi soils. Plant and Soil. 117, 135-141. 